\title{
Why I cannot pay a tribute to a dear friend
}

\author{
Por que não posso prestar homenagem a um amigo querido
}

Sarojini Nadimpally $\mathbf{1}^{\mathbf{2}}$

DOI: 10.1590/0103-11042020S124

IT IS INDEED HARD TO BELIEVE THAT I AM WRITING MY TRIBUTES to my dear friend Amit, who for over two decades played crucial and multiple roles in my life as mentor, hand-holder and colleague. What makes it more unbelievable is that we were together for almost 20 days in Savar, Dhaka in November 2018 - barely till a week before he left us forever - working closely on organising the International People's Health University (IPHU) and the 4th People's Health Assembly (PHA) of the People's Health Movement (PHM).

I can still vividly remember when I first met Amit at the Delhi Science Forum (DSF) office in 1994. That was the period when women's groups were actively involved in the campaign against population control policies, injectable contraceptives and coercive sterilisations. I was working with Jagori, a feminist organisation, those days. We were planning to come up with a strategy to stop the introduction of the injectable contraceptive Depo-Provera in the Family Welfare Programme. Friends from All India Drug Action Network (Aidan) asked me to become involved in a Public Interest Litigation (PIL) suit on bannable drugs that was being filed by DSF. A friend, Kalpana Mehta from Saheli, suggested I should meet a certain Dr. Amit Sengupta at his office in Saket J Block Market and consult him about the prayers for the intervention.

I was new in Delhi those days. I took the bus number 500 from South Extension to Saket, and walked into his office. The room was full of papers, files and books. I noticed someone sitting behind a table piled up with papers in a corner, barely visible. I asked him very politely that I wanted to meet Dr. Amit Sengupta. He looked up with a rather serious look and said, "I am Amit... yes, what is it about?". I was extremely nervous in the beginning, but slowly managed to have a conversation. He was very supportive and explained the process with great patience.

Over the years we met far more frequently and we both became a part of Jan Swasthya Abhiyan (JSA) and PHM. Amit was a founding member of the PHM and was instrumental in building the Movement as a globalpeople's health network bringing together movements, organisations, academics and activists committed to the struggle for health for all.

He was a major organizer the IPHU, a capacity building program for young health activists; and theWorld Health Organisation-Watch (WHO-Watch) in Geneva which intervenes with own statements into the debates at the World Health Assembly. Amit was the editor of the Global Health Watch (GHW), the civil society's alternative report to the WHO's World Health Report, which covers almost every aspect of the state of global health within the social-economic and

1 La Trobe University Melbourne, Australia.

dlegge@phmovement.org

2 People's Health Movement (PHM) -

Melbourne, Australia. political realities. He brought his enormous political, organisational and leadership capacity to both PHM and JSA. He could easily relate complex analytical information in a very simple manner to the grassroots health activists in JSA through his speeches, workshops and discussions.

Mentoring and building the capacities of young activists in this struggle was another commitment that he carried out through the IPHU and the WHO-Watch. He played a key role in 
conceptualising and coordinating the fourth PHA in Savar, Bangladesh, in mid November 2018, where more than 1400 people from around 73 countries came together to share their struggles and solidarity for collective action for health and social justice. These are just a drop in the vast ocean of Amit's contribution to this struggle. His politics and commitment, the imperative to work for a radical transformation in the way we approach actions and policies on health, literacy, science and technology was central to all of his countless contributions.

Most of all he never dithered from articulating his opinions or critiques about a range of issues related to health care, the role of pharma, of international NGOs, of the corporate sector, and the WHO. His politics, analysis and articulation on issues related to public health, access to medicines, Patent Laws to ensure inclusion of TRIPs flexibilities in the Indian Patents Act, and the range of other issues (frankly I don't know if there were too many that he did not have deep and informed insights about) have been a tremendous source of inspiration and mobilisation.

I still recall the heated discussions on Universal Health Coverage (UHC) a few years ago, after the release of the Report of the High Level Expert Group (HLEG) on UHC and also the shifts from global health organisations towards coverage. Amit had very clear thoughts on this. He never accepted the term Coverage; he believed in Care. According to him, $\mathrm{UHC}$ is essentially designed to universalize 'coverage' rather than 'care' which is built on, and lends itself to, standard neoliberal policies, steering policy-makers away from universal health options based on public systemsl. He argued that, in glossing over the importance of public provisioning of services, many proponents of UHC are actually interested in the creation of health markets that can be exploited by capital.

Amit brought his enormous political, organisational and leadership capacity to people's health and science movements. We are privileged to have had him as a co-traveller.

Amit physically left us on 28 November 2018. He leaves behind a monumental and wonderful legacy: the magic of his life, his intelligence, warmth, honesty, joy, wry humour and his steadfast commitment to a just and equitable world. We have so much more to learn from him: his work, his politics, his commitment. And so much more to do to celebrate and take forward all that he has done for us with his ceaseless, infectious optimism.

The untimely and unexpected demise of Amit is an irreparable loss to the community of the national and global health movement. JSA/PHM remembers him with a heavy heart and fondest of memories for being a long standing friend, colleague, and fellow comrade in the struggle for health for all.

At a personal level, I feel you are still around, just stepped out of town for a meeting and will be back in a few days. You will call any moment and ask in your typical style, "Kya chal raha hai? (what's going on?) Let's meet". Going through old mails, I think of you, your constant support, guidance and inspiration while working together, and our wonderful friendship. Adieu my dear friend, till our next meeting.

\section{Collaborator}

Nadimpally S (0000-0003-2494-616X)* is responsible for drafting the manuscript.
${ }^{*}$ Orcid (Open Researcher and Contributor ID).

\section{Reference}

1. Sengupta A. Universal Health Coverage: Beyond Rhetoric. 2013. [access in 2020 Jan 14]. Available in: http:// www.municipalservicesproject.org/publication/universal-health-coverage-beyond-rhetoric. 